\title{
Scorpions from the primeval subgenus Archaeotityus produce putative homologs of Tityus serrulatus toxins active on voltage-gated sodium channels
}

\author{
Borges A (1, 2), Jowers MJ (3), Bónoli S (2, 4), De Sousa L $(2,4)$
}

(1) Laboratory of Molecular Biology of Toxins and Receptors, Biomembranes Section, Institute of Experimental Medicine, Faculty of Medicine, Central University of Venezuela, Caracas, Venezuela; (2) Research Group on Applied Toxinology and Venomous Animals, University of Oriente, Anzoátegui Campus, Puerto La Cruz, Venezuela; (3) Superior Council of Scientific Research, Department of Etiology and Biodiversity Conservation, Biological Station of Doñana, La Cartuja Island, Seville, Spain; (4) Laboratory of Toxinology, Department of Physiological Sciences, School of Health Sciences, University of Oriente, Anzoátegui Campus, Puerto La Cruz, Venezuela.

\begin{abstract}
It has been proposed that the subgenus Archaeotityus comprises the most ancient species group within the medically important scorpion genus Tityus. cDNA encoding sodium-channel active toxins from the type species of this subgenus, Tityus clathratus (central Venezuela), have been isolated and sequenced. Two cDNAs were retrieved that encoded 61 amino acid-long putative neurotoxins named Tcl1 and Tcl2. Sequence identity was highest (87\%) when both were compared with $\beta$-toxin Ts1 from the Brazilian scorpion Tityus serrulatus and its homologs from T. bahiensis, T. stigmurus, and T. costatus. A Bayesian analysis indicated statistical support for the grouping of T. clathratus Tcl1 and Tcl 2 with Brazilian gammalike $\beta$-toxins, reinforcing previous phylogenetic studies which suggested an evolutionary relationship between the subgenus Archaeotityus and scorpion species inhabiting southeast South America belonging to the subgenus Tityus.
\end{abstract}

Key words: Archaeotityus, scorpions, scorpion toxins, Tityus, Tityus clathratus, Tityus serrulatus.

Tityus is unquestionably the most complex genus of scorpions from a taxonomical standpoint (1-4). It is annually responsible for numerous casualties in several endemic areas of Latin America and the Caribbean (1-7). With over 190 described species, thereistoxinologicaland clinical evidence indicating diversity in venom action and/or composition across Tityus distribution range. For example, envenoming by T. obscurus (formerly T. cambridgei) in northeastern Brazil typically presents with central neurotoxicity as opposed to the mainly autonomic manifestations associated with envenoming by $T$. serrulatus in the southeast (8). In Venezuela, envenoming by $T$. zulianus (Andean range) often produces respiratory arrest and death by pulmonary edema, whereas $T$. discrepans (north-central range) sting causes mainly pancreatic and gastrointestinal disorders $(6,9,10)$. Various degrees of toxicity have been associated with different Tityus venoms depending on the species, with medium lethal doses (in mice) ranging from 0.773 (T. stigmurus) to $12.136 \mathrm{mg} / \mathrm{kg}$ (T. obscurus) $(11,12)$. Notably, the smallest Tityus species, now belonging to the subgenus Archaeotityus, are only mildly toxic to humans (e.g. T. uruguayensis, T. pussilus, and T. silvestris) $(2,13-15)$. Toxicity of Tityus venoms is mostly due to the action of peptides targeting voltage-gated sodium channels $\left(\mathrm{Na}_{\mathrm{v}}\right)$, which have been classified as $\alpha$ - and $\beta$-toxins depending on whether they alter the kinetics of $\mathrm{Na}_{\mathrm{v}}$ inactivation or activation respectively (16).

Medically important Tityus species belong to the subgenera Atreus and Tityus, proposed by Lourenço (2), together with Archaeotityus, Brazilotityus, and Caribetityus, in order to organize the morphological groups already described within the genus. Archaeotityus 
species $(\mathrm{n}=24)$ comprise small $(18-40 \mathrm{~mm})$ and highly pigmented scorpions that are distributed throughout South America and the Caribbean and also Panamá and Costa Rica $(2,3,17,18)$. According to Mello-Leitão (19) and Lourenço (20), Archaeotityus occupies a plesiomorphic position among Tityus morphological groups/ subgenera. Thus, its variegated pigmentation and the stronger distal tooth of the dorsal median carinae are considered primitive characters because they are only found in the juvenile stages of all remaining Tityus species (19).

While most toxins in the genus have been isolated and characterized from species in subgenera Atreus and Tityus, only scarce information is available on the venoms and toxins produced by Archaeotityus. Envenomation by Archaeotityus sp. is of poor medical relevance, probably due to the low amount of venom injected by scorpions in this subgenus (21). Primary structure determination of Archaeotityus toxins should throw light on their evolutionary relationship with other Tityus toxins that target ion channels considering the primitive status of this subgenus as suggested previously $(19,20)$.

We undertook a molecular approach to recover amino acid sequences encoding $\mathrm{Na}_{\mathrm{v}}$-active toxins from Tityus clathratus, the type species of Archaeotityus. This approach has identified protein sequences with molecular masses that correspond to bona fide toxins from other Tityus species confirmed by mass spectrometry (10). Adult scorpions $(\mathrm{n}=12)$ were collected in Sanare, Lara State, western Venezuela $\left(09^{\circ} 45^{\prime} \mathrm{N}\right.$, $\left.69^{\circ} 20^{\prime} \mathrm{W}\right)$, and classified according to the taxonomic keys provided by González-Sponga (22). Total RNA was obtained from venom glands as described by Borges et al. (10). Animals were subjected to manual venom milking 48 hours before the dissection to increase production of toxin-encoding mRNAs (23). Scorpions subjected to dissection were deposited at the Scorpion Collection (CELT), Research Group on Applied Toxinology and Venomous Animals, Scholl of Health Sciences, University of Oriente, where they were given the catalog numbers CELT-1130 to CELT-1141.

Complementary DNA (cDNA) was synthesized from $1 \mu \mathrm{g}$ of total venom gland RNA using the modified oligo(dT) primer 5'-GGCCACGCGTCGACTAGTAC TTTTTTTTTTTTTTT-3 subsequently amplified via the polymerase chain reaction using the primer 5 ' - G G C CA C GCG T C G A C TA G TAC - 3 ' and the degenerate oligonucleotide 5'-GTTTATYWGCTGCTTITTKC-3'. The latter primer was designed to anchor at the $3^{\prime}$-end of the DNA region coding for the leader peptide of Tityus long-chain toxins under the amplification conditions described by Borges et al. (10).

PCR fragments were ligated to the vector pCR2.1-TOPO (Invitrogen, USA) and transformed into competent Escherichia coli $\mathrm{DH} 5 \alpha$ cells which were then plated onto LuriaBertani/agar plates containing 5-bromo-4chloro-3-indolyl-beta-D-galactopyranoside (X-Gal, $40 \mu \mathrm{g} / \mathrm{mL}$ ). Plasmids were isolated from recombinant colonies by the alkaline lysis method and sequenced using universal M13 primers in an automated ABI 3130XL DNA Sequencer (Applied Biosystems, USA) at the Nucleic Acid Sequencing Laboratory, Venezuelan Institute for Scientific Research (24).

Thirty seven clones were recovered from X-Galcontaining agar plates and subjected to DNA sequencing. Seven colonies encoded transcript Tcl1 and 30 encoded transcript Tcl2. Nucleotide sequences (312 and 314 bp respectively) are presented in Figure 1. GenBank accession numbers are HQ632799 (Tcl1) and HQ632800 (Tcl2). Both transcripts encode 71 amino acidlong proteins with the C-terminal-most 64 residues bearing high similarity to the mature peptide region of scorpion toxins targeting $\mathrm{Na}_{\mathrm{v}}$ channels based on comparisons using the BLAST server (http://blast.ncbi.nlm.nih.gov/Blast.cgi) and including the eight cysteines involved in formation of disulphide bridges.

The amino acid sequences of mature Tcl1 and $\mathrm{Tcl} 2$ are $79 \%$ identical to each other. Main differences occur at the C-terminus where Asp55, Arg56 and Arg60 (in Tcl1) are replaced by Ser55, Tyr56 and Thr60 in Tcl2. The deduced molecular masses of the processed 61-residuelong T. clathratus putative neurotoxins are (in Da) 6966 (for Tcl1) and 6913 (for Tcl2) assuming that the two C-terminal-most lysine residues of both proteins (Figure 1) are removed posttranslationally upon amidation via the amino group of Gly62, as is the case for other Tityus toxins (25).

Figure 2 shows the alignment of putative neurotoxins $\mathrm{Tcl} 1$ and $\mathrm{Tcl} 2$ with Tityus toxin 


\section{Tcl1}

AtC GGC GTG GTG GTG GAA AGT AAA GAA GGT TAT CTC ATG GAT CAC GAA GGC TGC 54 $\begin{array}{lllllllllllllllllll}\mathrm{I} & \mathrm{G} & \mathrm{V} & \mathrm{V} & \mathrm{V} & \mathrm{E} & \mathrm{S} & \mathrm{K} & \mathrm{E} & \mathrm{G} & \mathrm{Y} & \mathrm{L} & \mathrm{M} & \mathrm{D} & \mathrm{H} & \mathrm{E} & \mathrm{G} & \mathrm{C} & +11\end{array}$ AAA CtC Agt tgt tTC AtC AgA CCG GCG GGA tAC TGt gGt AgA GAA tgt tCg AtA 108 $\begin{array}{lllllllllllllllllll}\mathrm{K} & \mathrm{L} & \mathrm{S} & \mathrm{C} & \mathrm{F} & \mathrm{I} & \mathrm{R} & \mathrm{P} & \mathrm{A} & \mathrm{G} & \mathrm{Y} & \mathrm{C} & \mathrm{G} & \mathrm{R} & \mathrm{E} & \mathrm{C} & \mathrm{S} & \mathrm{I} & +29\end{array}$ AAG AAA GGG AAA AAT GGC TAC TGC CGC TGG CCA GCG TGT TAC TGC TAC GAT CTA 162 $\begin{array}{lllllllllllllllllll}\mathrm{K} & \mathrm{K} & \mathrm{G} & \mathrm{K} & \mathrm{N} & \mathrm{G} & \mathrm{Y} & \mathrm{C} & \mathrm{A} & \mathrm{W} & \mathrm{P} & \mathrm{A} & \mathrm{C} & \mathrm{Y} & \mathrm{C} & \mathrm{Y} & \mathrm{D} & \mathrm{L} & +47\end{array}$ CCC GGC TGG GCC AAA GTT TGG GAC AGA GCG ACG AAC AGA TGt GGg AAA AAA TGA 216 $\begin{array}{llllllllllllllllllllllll}\mathrm{P} & \mathrm{G} & \mathrm{W} & \mathrm{A} & \mathrm{K} & \mathrm{V} & \mathrm{W} & \mathrm{D} & \mathrm{R} & \mathrm{A} & \mathrm{T} & \mathrm{N} & \mathrm{R} & \mathrm{C} & \mathrm{G} & \mathrm{K} & \mathrm{K} & * & +64\end{array}$ ATTTCTCACCAGTGAAATTCTCTTCACAATGGAATTGTAACAATTAATGGAAATAGATTAAAATGTCTTGCA TAATAAAAAAAAAAAAAAAAAAAA

\section{Tcl2}

AtC GgC GTg GTg GTG GAA Agt AAA GAA GgT tAT CTC Atg GAT CGC GAA GgC tGC 54 $\begin{array}{lllllllllllllllllll}\mathrm{I} & \mathrm{G} & \mathrm{V} & \mathrm{V} & \mathrm{V} & \mathrm{E} & \mathrm{S} & \mathrm{K} & \mathrm{E} & \mathrm{G} & \mathrm{Y} & \mathrm{L} & \mathrm{M} & \mathrm{D} & \mathrm{R} & \mathrm{E} & \mathrm{G} & \mathrm{C} & +11\end{array}$ AAA CTC AGt TGt TtC ATC AGA CCG TCG GGA TAC TGt GGT AGA GAA TGt GAA AtA 108 $\begin{array}{lllllllllllllllllll}\mathrm{K} & \mathrm{L} & \mathrm{S} & \mathrm{C} & \mathrm{F} & \mathrm{I} & \mathrm{R} & \mathrm{P} & \mathrm{S} & \mathrm{G} & \mathrm{Y} & \mathrm{C} & \mathrm{G} & \mathrm{R} & \mathrm{E} & \mathrm{C} & \mathrm{E} & \mathrm{I} & +29\end{array}$ AAg AAA GGg TCC TCG GGC TAC TGC CGC TGG CTA GCG TGT TAC TGC TAC GGA CTA 162 $\begin{array}{lllllllllllllllllll}\text { K } & \text { K } & \text { G } & \text { S } & \text { S } & \text { G } & \text { Y } & \text { C } & \text { A } & \text { W } & \text { L } & \text { A } & \text { C } & \text { Y } & \text { C } & \text { Y } & \text { G } & \text { L } & +47\end{array}$ CCC GAT AGg GTg AAA GTT TGG AGC TAC GCA ACA AAC ACG TGC GGg AAA AAA TGA 216 $\begin{array}{lllllllllllllllllll}\mathrm{P} & \mathrm{D} & \mathrm{R} & \mathrm{V} & \mathrm{K} & \mathrm{V} & \mathrm{W} & \mathrm{S} & \mathrm{Y} & \mathrm{A} & \mathrm{T} & \mathrm{N} & \mathrm{T} & \mathrm{C} & \mathrm{G} & \mathrm{K} & \mathrm{K} & * & +64\end{array}$ ATCATTCACCACCGAAA ICTGTAAAAATGAATTGIAACAAGTTTGGAAAGAAATAAAAAGTCTTGTATTAAAA

ААААААААААААААААААААААААА

Figure 1. Nucleotide sequences of Tityus clathratus clones $\mathrm{Tcl} 1$ and $\mathrm{Tcl} 2$ and translated amino acid sequences. The predicted protein sequence is shown below the nucleotide sequence and is numbered starting from the putative $\mathrm{N}$-terminal residue, Lys. The signal peptide is underlined in the amino acid sequences; potential polyadenylation sites (AAUAAA and AAUUAA) are underlined in the nucleotide sequences (26). 


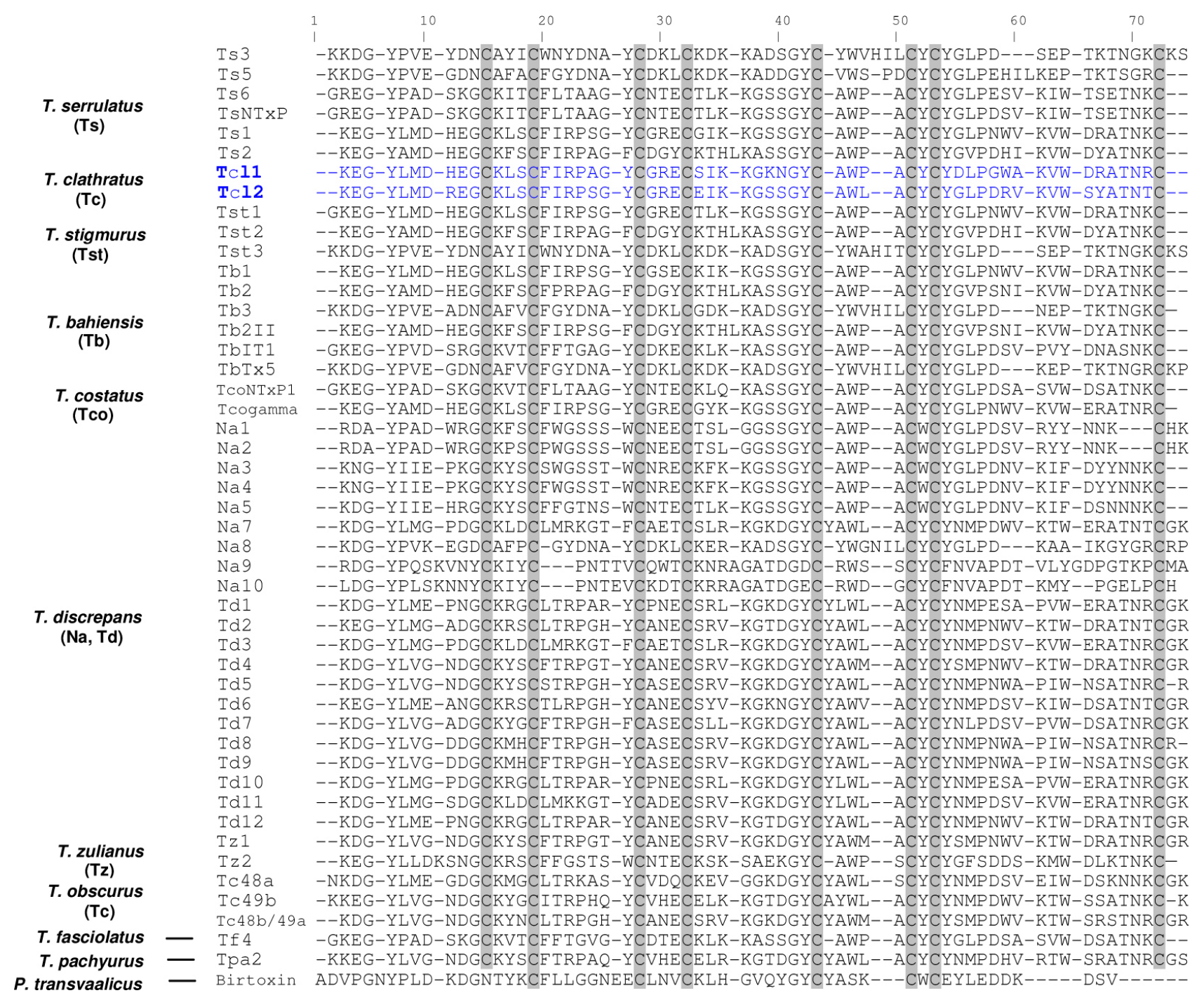

Figure 2. Alignment of amino acid sequences encoded by T. clathratus transcripts Tcl1 and Tcl2 (in blue) with $\mathrm{Na}_{v}$-active scorpion toxins from other Tityus species and birtoxin from Parabuthus transvaalicus. Sequences were aligned according to the positions of the cysteine residues (in gray). Residues potentially removed posttranslationally were excluded. Accession numbers (per scorpion species) for the listed sequences are: P. transvaalicus: birtoxin (P58752) (27); T. bahiensis (Tb): Tb1 (AAB36318), Tb2 (P56609), Tb3 (P56608), Tb2II (P60276), TbIT-1 (P60275) (28); TbTx5 (P0C5K8) (29); T. cambridgei (Tc): Tc48b/49a (P60213) (30), Tc48a (P60212) (31), Tc49b (P60214) (30); T. costatus (Tco): Tcogamma (clone 1) (AY740683), TcoNTxP1 (Q5G8A8) (32); T. discrepans (Td): Td1 (DQ075226), Td2 (FN392273), Td3 (DQ075229), Td4 (DQ075232), Td5 (DQ075237), Td6 (DQ075239), Td7 (DQ075242), Td8 (FN392275), Td9 (DQ075228), Td10 (DQ075230), Td11 (DQ075233), Td12 (DQ075234) (10), Na1 (FN392277), Na2 (FN392278), Na3 (FN392279), Na4 (FN392280), Na5 (FN392281), Na6 (FN392282), Na7 (FN392283), Na8 (FN392284), Na9 (FN392285), Na10 (FN392286) (33); T. fasciolatus (Tf):Tf4 (P83435) (12); T. pachyurus (Tpa):Tpa2 (P84631) (34); T. serrulatus (Ts):Ts1 (P15226), Ts2 (P68410), Ts3 (P01496), Ts5 (P46115), Ts6 (P45669) (35), TsNTxP (AAC25688) (36); T. stigmurus (Tst): Tst1 (AAB36321), Tst2 (AAB36322), Tst3 (P0C8X5) (35); T. zulianus (Tz): Tz1 (AY874060) (37), Tz2 (DQ075241) (37). 
sequences available from GenBank, which are from various origins in South America including Venezuela (T. discrepans and T. zulianus), the Brazilian Amazon/French Guiana region ( $T$. obscurus), the Brazilian southeast (T. serrulatus, T. bahiensis, T. costatus, and T. stigmurus), the Brazilian central region (T. fasciolatus), and Colombia (T. pachyurus). Sequences were aligned using the program Seaview v.4.2.11 (38). Of all aligned toxins, Tcl1 and Tcl2 show remarkable sequence resemblance ( $87 \%$ identity) to $T$. serrulatus Ts1 (also known as gamma toxin) and also to gamma-like toxins Tb1 (from T. bahiensis), Tst1 (from T. stigmurus) (35) and the peptide encoded by $T$. costatus clone 1 (Tcogamma) (32). Identity to $\beta$-toxin Ts 2 from $T$. serrulatus is lower (68 and $70 \%$ identity for Tcl 1 and $\mathrm{Tcl} 2$ respectively). Toxins from the scorpions T. discrepans and T. zulianus (which distribution ranges overlap with $T$. clathratus in Venezuela) and also those from T. obscurus and T. pachyurus display lower (50-67\%) identities to Tcl1 and Tcl2 compared with the Brazilian Ts1 and gamma-like toxins.

It is clear that Tcl1 and Tcl2 belong to the $\beta$-toxin family, bearing the same secondary structure elements found by Polikarpov et al. (39) in Ts1, the most abundant $T$. serrulatus $\beta$-toxin (40). Since Tityus venoms also contain $\alpha$-toxins (16), the fact that we did not retrieve cDNAs coding for putative T. clathratus $\alpha$-toxins could be either due to their absence in T. clathratus venom or that their cDNAs were not amplified under our conditions due to variations in the leader-peptide nucleotide sequence of $T$. clathratus $\alpha$-toxin genes, which may prevent the degenerate primer from anchoring at the selected site, identified as conserved amongst genes encoding other Tityus toxins (10). A thorough venom proteomic approach should help clarify whether this toxin group is produced by Archaeotityus species.

Both Tcl1 and Tcl2 share with Ts1 critical residues involved in the $\beta$-toxin pharmacophore (Glu26, Tyr22, Ile29) (41). Also, residue Gly24, which participates in antigenic recognition in Ts1, is conserved in both T. clathratus putative homologs (42). Gly28, also a residue of antigenic importance in Ts1, is not conserved in Tcl1 and $\mathrm{Tcl} 2$, but this position is also variable in other gamma-like toxins (42). Significantly, Gly24 and the pharmacophore residues lie within the $\alpha$-helical region, which is highly conserved in
Ts1, gamma-like toxins (Tb1, Tst1, Tcogmamma) and T. clathratus homologs (see alignment in Figure 2) $(39,42)$. The discontinuous antigenic epitope encompassing the amino- $\left({ }^{1} \mathrm{KEGY}^{5}\right)$ and carboxy- $\left({ }^{46} \mathrm{GLPXXVKV}{ }^{53}\right)$ terminal regions of T. serrulatus toxins is conserved in $\mathrm{Tcl} 2$, but the critical Gly46 is replaced in Tcll by Asp (43). At the gene level, both T. clathratus precursors exhibit $82 \%$ identity with respect to Ts1, with changes in Tcl1 and Tcl 2 cDNAs mostly comprising thirdposition replacements in the region encoding the central domain (residues 27-33).

A Bayesian analysis was performed to investigate the phylogenetic relationships of $T$. clathratus Tcl1 and Tcl 2 with Tityus toxins retrieved from GenBank. Figure 3 shows a consensus tree obtained after Bayesian reconstruction using the WAG model of protein evolution selected in ProtTest (44). Birtoxin, a three disulfide-bridge $\beta$-like toxin from the South African scorpion Parabuthus transvaalicus was chosen as outgroup since the probable ancestor of North and South American $\alpha$ - and $\beta$-toxins was a three-disulfide bridge toxin related to birtoxin $(27,45,46)$.

There is reasonable (Bayesian posterior probability, $\mathrm{BPP}=0.61$ ) supportforamonophyletic clade comprising toxins structurally and/or functionally related to the $\beta$-group which consists of two subclades. The first subclade $(\mathrm{BPP}=0.98)$ contains T. serrulatus Ts2 and Ts2-like toxins. The second subclade $(\mathrm{BPP}=0.87)$ comprises Ts1 and gamma-like toxins from T. bahiensis (Tb1), T. costatus (Tcogamma) and T. stigmurus (Tst1) with T. clathratus $\mathrm{Tcl} 2$ as a sister sequence. A subclade $(\mathrm{BPP}=0.85)$ internal to the gammalike group includes toxins from Venezuela (Tz1, Td1-Td12, Na7), Colombia (Tpa2) and the Brazilian Amazon/French Guiana region (Tc49b, Tc48b, Tc49a) with Tcl1 as a distantly related ( $p$-uncorrected distance: $40 \%$ ) sister sequence. Both Tcl1 and Tcl2 are equally distant to the subclade comprising Ts1 and related proteins ( $p$-uncorrected distance: 20\%), in agreement with their sequence homology to gamma-like toxins. The topology of the tree in the remaining branches cannot be assessed with certainty given the lower node support $(\mathrm{BPP}<0.50)$ for the groupings, with the exception of $\alpha$-toxins from T. serrulatus (Ts3, Ts5), T. bahiensis (Tb3), T. stigmurus (Tst3), and T. discrepans (Na8) which form a monophyletic group $(\mathrm{BPP}=1.0)$ lying outside the $\beta$-toxin clade as reported before $(45,46)$. 


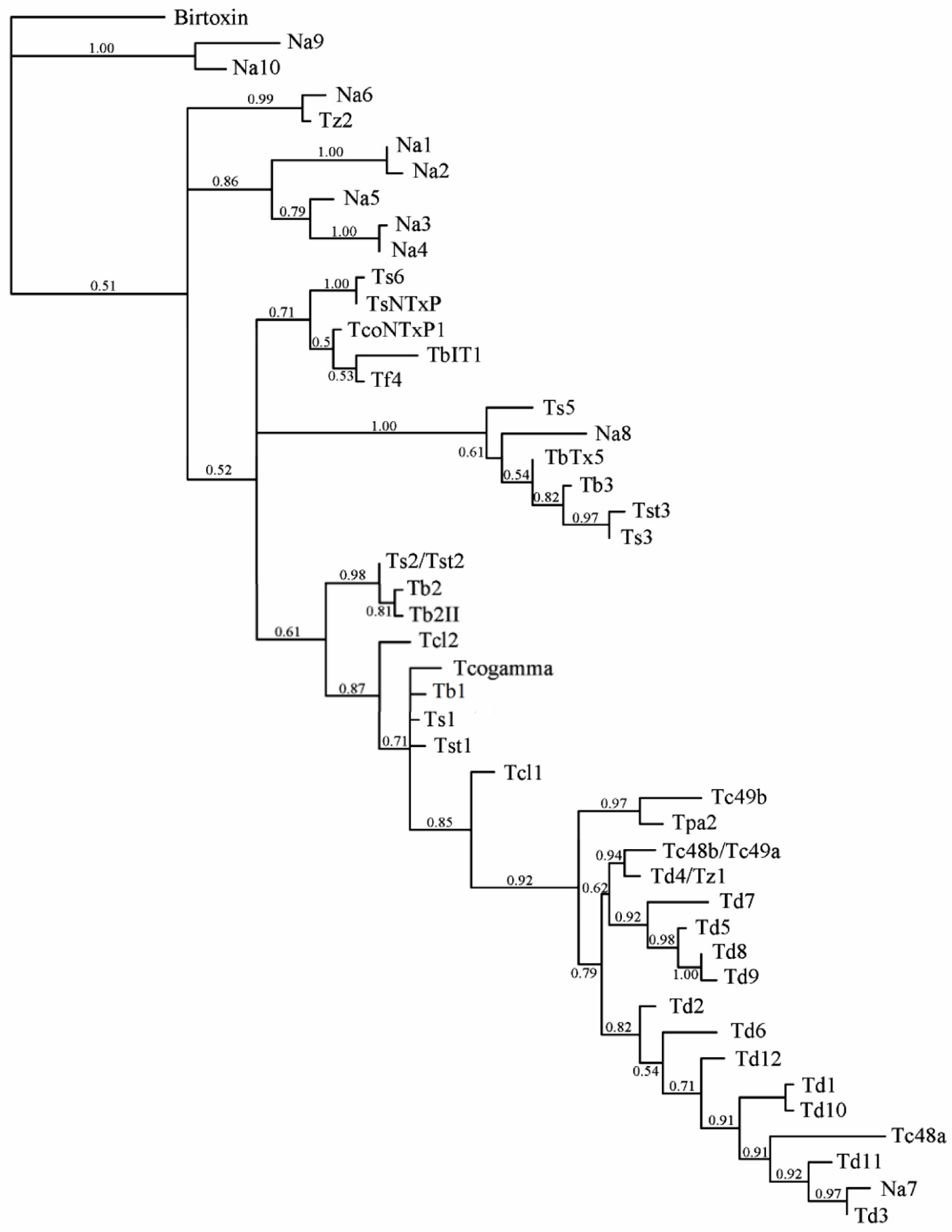

Figure 3. Bayesian maximum likelihood consensus phylogram depicting phylogenetic relationships of Tityus $\mathrm{Na}_{\mathrm{v}}$-active neurotoxins available from GenBank and T. clathratus $\mathrm{Tcl} 1$ and $\mathrm{Tcl} 2$ precursors isolated in this work. The sequence data set corresponds to the alignment presented in Figure 1. P. transvaalicus birtoxin was assigned as outgroup. Phylogenetic analysis was performed using the WAG model of protein evolution. Two Monte Carlo Markov chain were run 2,000,000 generations (burnin $=200,000$ ). Clade support was inferred by bootstrapping. Bayesian posterior probability (BPP) was calculated for branching points. Only nodes supported by BPP $>0.5$ are shown. 
The fact that the T. clathratus genome encodes $\mathrm{Na}_{\mathrm{v}}$ toxins with a very close structural fingerprint to Ts1 and its homologs indicates a toxinological affinity not anticipated in previous studies, especially considering that $T$. clathratus inhabits an area about $4000 \mathrm{~km}$ north of its south eastern Brazilian congeners and that it is morphologically unrelated to them. Homologs of T. serrulatus Ts1 had only been found so far in other Brazilian Tityus such as T. bahiensis, T. stigmurus and T. costatus, species belonging to the subgenus Tityus $(32,35)$. Significantly, T. discrepans and T. zulianus, two species sympatric with T. clathratus in Venezuela, do not produce such homologs but $\mathrm{Na}_{\mathrm{v}}$ toxins with divergent $\mathrm{N}$ - and $\mathrm{C}$-termini with respect to Ts1 $(10,33)$. In fact, in a recent phylogenetic analysis of Tityus scorpion $\mathrm{Na}_{\mathrm{v}}$ toxins, Guerrero-Vargas et al. (47) revealed a strong toxinological divergence among T. pachyurus, T. obscurus, T. discrepans and T. zulianus (in the subgenus Atreus) from the northern part of the Amazon Basin, and T. serrulatus, T. bahiensis, T. stigmurus, T. costatus and T. fasciolatus (in the subgenus Tityus), which live south of the Amazon.

Thus far T. clathratus is the only species from the north of the Amazon Basin producing putative toxin homologs of southern Brazilian Tityus, which provides further support for the evolutionary relationship between subgenera Archaeotityus (which has a trans-Amazonian distribution) and Tityus and its separation from the subgenus Atreus as suggested previously by Borges et al. (4). The latter authors, in their molecular phylogenetic analysis of 21 Tityus species using two mitochondrial DNA markers (cytochrome oxidase subunit 1 and ribosomal 16S rRNA), found that the Archaeotityus type species, T. clathratus, groups with the Brazilian T. serrulatus into a single clade which strongly diverges (53-57\% nucleotide divergence) with respect to its other congeners in Venezuela, Trinidad and Panama in the subgenus Atreus.

No hypothesis for relationships amongst Tityus subgenera had been put forward prior to the present findings or those of Borges et al. (4). Only Lourenço (20) has suggested that the primitive Archaeotityus is closely related to Caribetityus, a subgenus endemic to the Caribbean island of Hispaniola (currently Dominican Republic and Haiti) and that the Cuban genera Alayotityus and Tityopsis, together with Caribetityus and Archaeotityus, are the possible proto-elements of continental Tityus, all sharing a common ancestor in South America.

Probably our results implicate that such common ancestor, evolutionary and toxinologically shared by subgenera Archaeotityus and Tityus, was distributed in South America before formation of the Amazon Basin and therefore prior to cladogenesis of the Atreus group, mainly restricted to the northern part of the subcontinent and whose species evolved different toxin repertoires (47). It is clear that the molecular analysis of more Archaeotityus species is needed to evaluate whether they produce Ts 1 homologs as T. clathratus, and also to determine their phylogenetic affinity with species in the subgenus Tityus.

All in all, this research constitutes an initial point to study the evolution of Tityus venoms, the most speciose of all scorpion genera, comparing the putative toxins from an ancient species group with toxins from other species within the genus that have been well characterized.

\section{ACKNOWLEDGMENTS}

We are thankful to Lic. Javier Valera Leal and Lic. Aleikar Vásquez for their help during scorpion collection. Financial support from the Council for Scientific and Humanistic Development, Central University of Venezuela, and the Investigation Council of University of Oriente is gratefully acknowledged.

\section{COPYRIGHT}

(C) CEVAP 2012

\section{SUBMISSION STATUS}

Received: March 23, 2012.

Accepted: August 31, 2012.

Abstract published online: September 3, 2012.

Full paper published online: November 30, 2012.

\section{CONFLICTS OF INTEREST}

The authors declare no conflicts of interest.

\section{FINANCIAL SOURCE}

The Council for Scientific and Humanistic Development, Central University of Venezuela (CDCH-UCV) grant n. PG-09-7767-2009/2 (to Adolfo Borges) and Investigation Council of University of Oriente grant n. CI-3-0406021342/07 (to Leonardo de Sousa) provided the financial grants. 


\section{ETHICS COMMITTEE APPROVAL}

The present study was approved by the Ethics Committee of the Institute of Experimental Medicine, Central University of Venezuela.

\section{CORRESPONDENCE TO}

Adolfo Borges, Instituto de Medicina Experimental, Facultad de Medicina, Universidad Central de Venezuela, Apartado Postal 50587, Caracas 1050, Venezuela. Phone: +58212 6053608. Fax: +58212 6628877. Email: borges. adolfo@gmail.com.

\section{REFERENCES}

1. Lourenço WR. Scorpions of Brazil. Paris: Editions L'If; 2002.

2. Lourenço WR. Nouvelle proposition de découpage sous-générique du genre Tityus C.L. Koch, 1836 (Scorpiones, Buthidae). Bol SEA. 2006;39:55-67.

3. Rojas-Runjaic FJ, De Sousa L. Catálogo de los escorpiones de Venezuela (Arachnida: Scorpiones). Bol SEA. 2007; 40:281-307.

4. Borges A, Bermingham E, Herrera N, Alfonzo MJ, Sanjur O. Molecular systematics of the neotropical scorpion genus Tityus (Buthidae): The historical biogeography and venom antigenic diversity of toxic Venezuelan species. Toxicon. 2010;55(2-3):436-54.

5. ChippauxJP, Goyffon M. Epidemiology of scorpionism: a global appraisal. Acta Trop. 2008;107(2):71-9.

6. Borges A, Rojas-Runjaic FJ, Diez N, Faks JG, Op den Camp, HJ, De Sousa L. Envenomation by the scorpion Tityus breweri in the Guayana Shield, Venezuela: Report of a case, efficacy and reactivity of antivenom and proposal for a toxinological partitioning of the Venezuelan scorpion fauna. Wilderness Environ Med. 2010;21(4):281-9.

7. Borges A, Miranda RJ, Pascale JM. Scorpionism in Central America, with special reference to the case of Panama. J Venom Anim Toxins incl Trop Dis. 2012;18(2):130-43.

8. Pardal PP, Castro LC, Jennings E, Pardal JS, Monteiro MR. Epidemiological and clinical aspects of scorpion envenomation in the region of Santarém, Pará, Brazil. Rev Soc Bras Med Trop. 2003;36(3):349-53.

9. Mazzei de Dàvila CA, Dàvila DF, Donis JH, de Bellabarba GA, Villarreal V, Barboza JS. Sympathetic nervous system activation, antivenin administration and cardiovascular manifestations of scorpion envenomation. Toxicon. 2002;40(9):1339-46.

10. Borges A, García CC, Lugo E, Alfonzo MJ, Jowers MJ, Op den Camp HJ. Long-chain toxin diversity in Tityus zulianus and Tityus discrepans venoms (Scorpiones, Buthidae): Molecular, immunological and mass spectral analyses. Comp Biochem Physiol C Toxicol Pharmacol. 2006;142(3-4):240-52.

11. Nishikawa AK, Caricati CP, Lima ML, Dos Santos MC, Kipnis TL, Eickstedt VR, et al. Antigenic crossreactivity among the venoms from several species of
Brazilian scorpions. Toxicon. 1994;32(8):989-98.

12. Wagner S, Castro MS, Barbosa JA, Fontes W, Schwartz EN, Sebben A, et al. Purification and primary structure determination of Tf4, the first bioactive peptide isolated from the venom of the Brazilian scorpion Tityus fasciolatus. Toxicon. 2003;41(7):737-45.

13. Simó M, Toscano-Gadea C. Arácnidos Peligrosos. In: Viera C, editor. Arácnidos del Uruguay. Montevideo: Editorial Banda Oriental; 2011. p. 215-27.

14. Albuquerque CM, Porto TJ, Amorim ML, Santana Neto P de L. Scorpionism caused by Tityus pusillus Pocock, 1893 (Scorpiones; Buthidae) in State of Pernambuco. Rev Soc Bras Med Trop. 2009;42(6):2068.

15. Neto HF, Pardal PP. Escorpiões e escorpionismo na área metropolitana de Belém e arredores, Estado do Pará, Brasil (Chelicerata, Scorpiones). An Acad Med.1996;7:31-5.

16. Rodríguez de la Vega RC, Possani LD. Overview of scorpion toxins specific for $\mathrm{Na}+$ channels and related peptides: biodiversity, structure-function relationships and evolution. Toxicon. 2005;46(8):831-44.

17. Lourenço WR. Analyse taxonomique des scorpions du groupe Tityus clathratus Koch, 1845 (Scorpiones, Buthidae). Bull Mus Hist Nat Paris. 1984;6(2):349-60.

18. Lourenço WR. Biogéographie des espèces du groupe naturel "Tityus clathratus" (Chelicerata, Scorpiones, Buthidae). Bull Mus Hist Nat Paris. 1992;14(2):47381.

19. Mello-Leitão C. Escorpiões Sul-americanos. Arq Museu Nac. 1945;40:1-468.

20. Lourenço WR. Origin and affinities of the Caribbean scorpiofauna. In: Llorente-Bousquets J, Morrone JJ, editors. Regionalización biogeográfica en Iberoamérica y tópicos afines. Ciudad de Mexico: Ediciones de la Universidad Nacional Autónoma de México; 2005. p. 383-94.

21. D’Suze G, Moncada S, González C, Sevcik C, Alagón A. Antigenic cross-reactivity between sixteen venoms from scorpions belonging to six genera. Clin Toxicol (Phila). 2007;45(2):158-63.

22. González-Sponga MA. Guía para identificar Escorpiones de Venezuela. Caracas: Cuadernos Lagoven; 1996. p. 204.

23. Alami M, OuafikL, Céard B, Legros C, Bougis P, MartinEauclaire MF. Characterization of the gene encoding the a-toxin AmmV from the scorpion Androctonus mauretanicus. Toxicon. 2001;39(10):1579-85.

24. Sambrook J, Fritsch EF, Maniatis T. Molecular Cloning: a laboratory manual. Cold Spring Harbor: Cold Spring Harbor Laboratory Press New York; 1989.

25. Possani LD, Becerril B, Delepierre M, Tytgat J. Scorpion toxins specific for $\mathrm{Na}^{+}$-channels. Eur J Biochem. 1999;264(2):287-300.

26. Wahle E, Ruegsegger U. 3'-End processing of pre-mRNA in eukaryotes. FEMS Microbiol Rev. 1999;23(3):277-95.

27. Inceoglu $\mathrm{B}$, Lango J, Wu J, Hawkins P, Southern J, Hammock BD. Isolation and characterization of a novel type of neurotoxic polypeptide from the venom of the South African scorpion Parabuthus transvaalicus 
(Buthidae). Eur J Biochem. 2001;268(20):5407-13.

28. Pimenta AM, Martin-Eauclaire $M$, Rochat $H$, Figueiredo SG, Kalapothakis E, Afonso LC, et al. Purification, amino-acid sequence and partial characterization of two toxins with anti-insect activity from the venom of the South American scorpion Tityus bahiensis (Buthidae). Toxicon. 2001;39(7):1009-19.

29. Kalapothakis E, Jardim S, Magalhaes AC, Mendes TM, De Marco L, Afonso LC, et al. Screening of expression libraries using ELISA: identification of immunogenic proteins from Tityus bahiensis and Tityus serrulatus venom. Toxicon. 2001;39(5):679-85.

30. Batista CV, Zamudio FZ, Lucas S, Fox JW, Frau A, Prestipino G, et al. Scorpion toxins from Tityus cambridgei that affect $\mathrm{Na}(+)$-channels. Toxicon. 2002;40(5):557-62.

31. Batista CV, del Pozo L, Zamudio FZ, Contreras S, Becerril B, Wanke E, et al. Proteomics of the venom from the Amazonian scorpion Tityus cambridgei and the role of prolines on mass spectrometry analysis of toxins. J Chromatogr B Analyt Technol Biomed Life Sci. 2004;803(1):55-66.

32. Diego-García E, Batista CV, García-Gómez BI, Lucas S, Candido DM, Gomez-Lagunas F, et al. The Brazilian scorpion Tityus costatus Karsch: genes, peptides and function. Toxicon. 2005;45(3):273-83.

33. D’Suze G, Schwartz EF, García-Gómez BI, Sevcik C, Possani LD. Molecular cloning and nucleotide sequence analysis of genes from a cDNA library of the scorpion Tityus discrepans. Biochimie. 2009;91(8):1010-9.

34. Barona J, Batista CV, Zamudio FZ, Gomez-Lagunas F, Wanke E, Otero R, et al. Proteomic analysis of the venom and characterization of toxins specific for $\mathrm{Na}+-$ and $\mathrm{K}+$-channels from the Colombian scorpion Tityus pachyurus. Biochim Biophys Acta. 2005;1764(1):7684.

35. Becerril B, Corona M, Coronas FI, Zamudio F, Calderon-Aranda ES, Fletcher PL Jr, et al. Toxic peptides and genes encoding toxin gamma of the Brazilian scorpions Tityus bahiensis and Tityus stigmurus. Biochem J. 1996;313:753-60.

36. Chávez-Olórtegui C, Kalapothakis E, Ferreira AM, Ferreira AP, Diniz CR. Neutralizing capacity of antibodies elicited by a non-toxic protein purified from the venom of the scorpion Tityus serrulatus. Toxicon. 1997;35(2):213-21.

37. Borges A, Alfonzo MJ, García CC, Winand NJ, Leipold E, Heinemann SH. Isolation, molecular cloning and functional characterization of a novel beta toxin from the Venezuelan scorpion, Tityus zulianus. Toxicon. 2004;43(6):671-84.
38. Gouy M, Guindon S, Gascuel O. SeaView version 4: a multiplatform graphical user interface for sequence alignment and phylogenetic tree building. Mol Biol Evol. 2010;27(2):221-4.

39. Polikarpov I, Junior MS, Marangoni S, Toyama MH, Teplyakov A. Crystal structure of neurotoxin Ts1 from Tityus serrulatus provides insights into the specificity and toxicity of scorpion toxins. J Mol Biol. 1999;290(1):175-84.

40. Martin-Eauclaire MF, Céard B, Ribeiro AM, Diniz $\mathrm{CR}$, Rochat H, Bougis PE. Molecular cloning and nucleotide sequence analysis of a cDNA encoding the main beta-neurotoxin from the venom of the South American scorpion Tityus serrulatus. FEBS Lett. 1992;302(3):220-2.

41. Cohen L, Karbat I, Gilles N, Froy O, Corzo G, Angelovici R, Gordon D, Gurevitz M. Dissection of the functional surface of an anti-insect excitatory toxin illuminates a putative "hot spot" common to all scorpion beta-toxins affecting $\mathrm{Na}+$ channels. J Biol Chem. 2004;279(9):8206-11.

42. Machado de Ávila RA, Alvarenga LM, Tavares CA, Molina F, Granier C, Chávez-Olórtegui C. Molecular characterization of protective antibodies raised in mice by Tityus serrulatus scorpion venom toxins conjugated to bovine serum albumin. Toxicon. 2004;44(3):23341.

43. Duarte CG, Alvarenga LM, Dias-Lopes C, Machadode-Avila RA, Nguyen C, Molina F, et al. In vivo protection against Tityus serrulatus scorpion venom by antibodies raised against a discontinuous synthetic epitope. Vaccine. 2010;28(5):1168-76.

44. Abascal F, Zardoya R, Posada D. ProtTest: Selection of best-fit models of protein evolution. Bioinformatics. 2005;21(9):2104-5.

45. Froy O, Gurevitz M. New insight on scorpion divergence inferred from comparative analysis of toxin structure, pharmacology and distribution. Toxicon. 2003;42(5):549-55.

46. Zuo XP, Ji YH. Molecular mechanisms of scorpion toxins acting on sodium channels. Insight into their diverse selectivity. Mol Neurobiol. 2004;30(3):265-78.

47. Guerrero-Vargas JA, Mourão CB, QuinteroHernández V, Possani LD, Schwartz EF. Identification and phylogenetic analysis of Tityus pachyurus and Tityus obscurus novel putative $\mathrm{Na}^{+}$-channel scorpion toxins. PLoS One. 2012;7(2):e30478. 